\title{
Comment
}

\section{United States - Measures Affecting the Cross-Border Supply of Gambling and Betting Services}

\section{Prepared for the ALI Project on the Case Law of the WTO}

\author{
FEDERICO ORTINO
}

Lecturer in International Economic Law, Kings College, London

My remarks will focus mainly on the following two issues: (a) the scope of the per se prohibition in Article XVI GATS and (b) the nature of the balancing exercise carried out under Article XIV GATS. ${ }^{1}$ I will also add two brief points on the 'burden of proof' and 'availability of alternative measures' under the least-traderestrictive test of Article XIV GATS.

\section{Scope of Article XVI GATS}

The Appellate Body's apparent reading of Article XVI GATS to cover measures having an effect equivalent to an express quantitative restriction raises certain fundamental issues regarding the balance struck by the GATS between liberalizing trade in services and recognizing a Member's right to regulate the provision of services. While the reach of the Appellate Body's reading of Article XVI GATS is not altogether clear, the Gambling decision may be compared with the 1974 landmark decision by the European Court of Justice in Dassonville, which expanded the scope of the prohibition under Article 28 of the Treaty of Rome to 'all trading rules enacted by Member States which are capable of hindering, directly or indirectly, actually or potentially, intra-community trade'. First of all, I would argue that this is not the most plausible reading of Article XVI GATS. Secondly, I am not certain of the advantages of such a broad interpretation of Article XVI.

1 I have raised several criticisms towards the way the Appellate Body has reached its conclusion with regard to the scope of Article XVI GATS in 'Treaty Interpretation and the WTO Appellate Body Report in US - Gambling: A Critique’, JIEL (2006). 
On the first point, I would argue that the rationale behind Article XVI GATS appears to lie in the presumed absence of a legitimate public policy justifying the measures listed under Article XVI. In light of the rigid discipline to which these measures are subject (per se prohibition, rather than 'reasonableness' or 'non-discrimination'), it is indeed plausible that, in the minds of the treaty drafters, the underlying rationale of Article XVI is a presumption that the measures listed in subparagraph $(2)(\mathrm{a})-(\mathrm{f})$ generally lack any legitimate policy justification (in much the same way as quotas and other restrictions on the importation of goods). ${ }^{2}$ Accordingly, in the ideal world envisioned by the drafters of the GATS, ${ }^{3}$ the measures listed therein should be in principle prohibited. Nonetheless, since such a presumption is based on a general value judgment (which may not be applicable in all circumstances), the drafters provided for the possibility that the market-access limitations of Article XVI may, in exceptional circumstances, be justified through recourse to Article XIV GATS. In other words, the above presumption is a rebuttable one.

The dividing line between what is per se prohibited by Article XVI and what is subjected to nondiscrimination and reasonableness standards may be fine, but it is there! While it is conceivable that the drafters of the GATS viewed formal 'quotas' as domestic measures that could not be permitted under WTO law since they lacked a legitimate policy justification, it is unconceivable that they also included within such a category of 'incriminated' measures any domestic regulation that has simply an effect equivalent to a quota (i.e., restricting access to national markets). Banning (online) gambling, like imposing an entry exam for lawyers or a minimum-capital requirement for banks, undeniably pursues legitimate policy objectives. It seems to follow that, even if these types of measures potentially restrict market access, they should not be subjected to the rigid approach (per se prohibition) of Article XVI.

Consider, for example, the case of a license requirement imposed by State A on the opening of a new restaurant in its territory. If the granting of the license in question depends on a pre-established quota ('only 5 restaurants may operate in the relevant area') or is based on an economic-needs test ('new restaurant licenses

2 This presumption may also stem from the perception that quantitative restrictions have a discriminatory or protectionist tendency since, by limiting how many suppliers operate within a specific market, they are bound to constitute protection to existing domestic operators (sub-paragraph (f) of Article $\mathrm{XVI}$ :(2) seems to confirm this view). However, this is not always true, especially with regard to new service fields or products and to developing countries. In these circumstances, Article XVI GATS could even be perceived as a pro-competitive instrument, insofar as it prohibits national governments to protect, not just domestic, but any incumbent service supplier.

3 As previously noted, (similar to tariffs) Article XVI market-access limitations are not prohibited immediately because it would not be economically and thus politically feasible to do so. For example, protection of a specific infant-service industry might be achieved through one of the quantitative measures listed in Article XVI. However, in the ideal world designed by the GATS, these types of justification are only temporary, and thus market-access restrictions are subject to the progressive liberalization 'commitments' in Article XIX GATS. 
shall be granted only in the case of unsatisfied customers' demand'), then that requirement falls within the scope of application of Article XVI and is per se prohibited (as long as State A has entered a market-access commitment). On the other hand, if the granting of the restaurant license depends on the quality of the service supplied or on the ability of the supplier to supply the service, the measure falls outside the scope of Article XVI (and is potentially subjected to the disciplines of Articles XVII and VI). The difference between the two cases lies on the criteria employed in determining whether or not the license should be granted: while a simple numerical criterion or an economic-needs test is presumed to constitute illegitimate grounds upon which to base a limitation on market access, the quality of the service supplied or the ability of the supplier to supply the specific service are deemed to constitute legitimate regulatory policies. ${ }^{4}$

Shortly on the second point: are there any advantages of the broad interpretation of Article XVI? Clearly, a broad reading of Article XVI (such as the one rendered by the Appellate Body in Gambling) would expand the liberalizing scope of GATS at least for the sectors that Members have already committed to in their schedules. However, such a broad reading may also have the likely effect that, in future negotiations under the GATS, Members would be very reluctant to commit to the 'Market Access' disciplines of Article XVI making that provision 'dead letter'. In this regard, it would be interesting to assess whether the decision in Gambling has had already some effect in some of the recent accession negotiations.

\section{Balancing under Article XIV GATS ?}

Since the Appellate Body Report in Korea-Beef, there appears to be a contradiction in the approach to the 'necessity test' under the general exception provisions of Articles XX GATT and XIV GATS. Gambling simply confirms this apparent contradiction. In the Appellate Body's view, a determination of whether a measure is 'necessary' within the context of Article XX GATT or Article XIV GATS involves in every case a process of weighing and balancing a series of factors that prominently include 'the contribution made by the compliance measure to the enforcement of the law or regulation at issue, the importance of the common interests or values protected by that law or regulation, and the accompanying impact of the law or regulation on imports or exports'. ${ }^{5}$ At the same time, the

\footnotetext{
4 There is also empirical evidence that a measure, which has been found to violate a per se prohibition type of discipline (such as Article II or Article XI GATT), has never been found to be justified on the basis of one of the legitimate public-policy objectives listed in the general-exception provision (Article XX GATT). The only case where Article XX GATT was successfully employed to justify a violation of Article XI was US-Shrimp 21.5. However, the measure at issue in that dispute was the border arm of an internal regulation and thus should have been reviewed on the basis of Article III rather than Article XI GATT. For a fuller discussion of the issue see Ortino, Basic Legal Instruments for the Liberalisation of Trade: A Comparative Analysis of EC and WTO Law (Oxford: Hart 2004) at 220-221.

5 Appellate Body Report on Korea-Beef, para. 164.
} 
Appellate Body firmly recognizes that WTO Members have the right to determine for themselves the level of protection. ${ }^{6}$ Is the necessity test a 'cost/benefit' or 'proportionality stricto sensu' test, as the former language may seem to suggest, or more simply a 'cost/effectiveness' or 'least-trade-restrictive' test, as the latter sentence implies?

I believe that the 'weighing and balancing' test advanced by the Appellate Body in Korea-Beef and applied in Gambling should not be equated to what in EC law terminology is the test of 'proportionality stricto sensu', according to which the Court of Justice balances the national interest in pursuing a legitimate public policy against the Community interest in ensuring the free movement of goods and services. On the basis of this test, for example, it would be possible to strike down a national measure even if it is found to be 'necessary' to pursue a legitimate aim like environmental protection, on the basis that, on balance, the measure's negative effects on trade are disproportionate to its benefits on the environment.

This apparent contradictory language with regard to the meaning of the term 'necessary' within the general exceptions in the GATT and GATS clearly evidences the struggle in which the Appellate Body finds itself in attempting to deal with two diverging needs: 'flexible application' and 'legal certainty'. If the Appellate Body recognizes the inescapable and indispensable flexibility in applying concepts such as the 'necessity' requirement, it also tries to provide the elements upon which to base a 'necessity' determination. Although in doing so the Appellate Body did put forward certain new elements, it seems that this general approach does not differ substantially from the least-trade-restrictive test as enunciated in the famous Section 337 GATT Panel Report. The several factors included in the weighing and balancing process in Korea-Beef are all to be employed in order to determine whether there exists an alternative measure that (1) is less restrictive than that found to violate one of the obligations of the GATT and (2) may equally protect the relevant public policy pursued by the Member. ${ }^{7}$

It should be stressed that even the necessity test understood as a least-traderestrictive test may involve some form of 'balancing'. For example, determining what is the 'appropriate level of protection' (pursued by the regulating Member) is not a scientific exercise, and it grants judicial organs a certain margin of appreciation (determining Korea's relevant level of consumer protection in Korea-Beef was a key, and somewhat, controversial issue). Similarly, deciding whether a less trade-restrictive alternative achieves the same level of protection (as well as deciding whether an alternative is less restrictive) involves a certain margin of appreciation. Clearly this would not be 'balancing' of the same kind as that

6 Appellate Body Report on Korea-Beef, para. 176.

7 I would submit that the Appellate Body's reference to the extent of the restrictive effects on international commerce produced by the GATT-inconsistent compliance measure should not be regarded as introducing this type of 'weighing and balancing', but simply as the necessary limb in the determination of the existence of a less-restrictive measure that may equally secure compliance with the relevant 'laws and regulations'. 
characterizing cost-benefit balancing; rather it is a form of balancing that cannot be avoided even in applying 'necessity' and 'less trade-restrictive' tests. This is what the Appellate Body was trying to grapple with in Korea-Beef: this could explain the reference to 'a range of degrees of necessity', the so-called 'continuum', as well as the reference to the 'trade costs' and 'contribution to the realization of the end pursued'. Also, the reference to the importance of the values protected by the regulating Member (the first criterion mentioned by the Appellate Body in Korea-Beef) may also be simply an attempt by the AB to come to face with an unavoidable factor at play in applying the 'necessity test' (rather than as part of a cost-benefit balancing). The importance of the public-policy goal will affect the above-mentioned 'balancing', which the judicial organs need to carry out within the 'least-trade-restrictive' test.

\section{Burden of proof and availability of measures}

The Appellate Body application of the 'necessity test' in Gambling did have two new features: one dealing with the burden of proof and one with the availability of alternative measures.

First, the Appellate Body emphasizes that it is for the defending party to make a prima facie case that its measure is 'necessary' by putting forward evidence and arguments in respect of the relevant factors to be weighted and balanced. The focus here is on the measures under review. If the defending party is successful in making a prima facie case of necessity, then it is for the complaining party to raise WTO-consistent alternative measures (capable of achieving the same level of protection) that the responding party should have taken. The focus here is on the alternative measures. ${ }^{8}$

Second, the Appellate Body recognizes expressly in Gambling that a purely 'theoretical alternative' is not enough to rebut a prima facie case of necessity; for example, if 'the responding Member is not capable of taking it, or where the measure imposes ... prohibitive costs or substantial technical difficulties' ${ }^{9}$ This statement allows WTO dispute settlement panels some flexibility in determining the existence of alternative measures reasonably available when the defending Member is, for example, a developing country. 